\title{
Mood and anxiety disorders across the adult lifespan: a European perspective
}

\author{
R. D. McDowell ${ }^{1 *}$, A. Ryan ${ }^{1}$, B.P. Bunting ${ }^{2}$, S. M. O'Neill ${ }^{2}$, J. Alonso ${ }^{3}$, R. Bruffaerts ${ }^{4}$, R. de Graaf ${ }^{5}$, \\ S. Florescu ${ }^{6}$, G. Vilagut ${ }^{7}$, J. M. C. de Almeida ${ }^{8}$, G. de Girolamo9 ${ }^{\text {, J. M. Haro }}{ }^{10}$, H. Hinkov ${ }^{11}$, \\ V. Kovess-Masfety ${ }^{12}$, H. Matschinger ${ }^{13}$ and T. Tomov ${ }^{14}$
}

${ }^{1}$ Institute of Nursing \& Health Research, University of Ulster, Coleraine, N. Ireland; ${ }^{2}$ Psychology Research Institute, University of Ulster, Londonderry, N. Ireland; ${ }^{3}$ Health Services Research Unit, IMIM-Institut Hospital del Mar d'Investigacions Mèdiques, Barcelona, Spain; CIBER en Epidemiología y Salud Pública (CIBERESP), Spain; Department of Experimental and Health Sciences, Pompeu Fabra University (UPF), Barcelona, Spain; ${ }^{4}$ Universitair Psychiatrisch Centrum - KU Leuven (UPC-KUL), KU Leuven, Leuven, Belgium; ${ }^{5}$ Netherlands Institute of Mental Health and Addiction, Utrecht, the Netherlands; ${ }^{6}$ National School of Public Health, Management and Professional Development, Bucharest, Romania; ${ }^{7}$ Health Services Research Unit, IMIM-Institut Hospital del Mar d'Investigacions Mèdiques, Barcelona, Spain; CIBER en Epidemiología y Salud Pública (CIBERESP), Spain; ${ }^{8}$ Departamento de Saúde Mental, Faculdade de Ciências Médicas, Portugal; ${ }^{9}$ IRCCS Centro S. Giovanni di Dio Fatebenefratelli, Italy; ${ }^{10}$ Parc Sanitari Sant Joan de Déu, Universitat de Barcelona, CIBER en Salud Mental, Spain; ${ }^{11}$ National Center for Public Health Protection, Bulgaria; ${ }^{12}$ EHESP, EA4069, Université Paris Descartes, SPC France; ${ }^{13}$ University of Leipzig, Leipzig, Germany and ${ }^{14}$ Department of Psychiatry, Alexandrovsaka Hospital, Bulgaria

Background. The World Mental Health Survey Initiative (WMHSI) has advanced our understanding of mental disorders by providing data suitable for analysis across many countries. However, these data have not yet been fully explored from a cross-national lifespan perspective. In particular, there is a shortage of research on the relationship between mood and anxiety disorders and age across countries. In this study we used multigroup methods to model the distribution of 12-month DSM-IV/CIDI mood and anxiety disorders across the adult lifespan in relation to determinants of mental health in 10 European Union (EU) countries.

Method. Logistic regression was used to model the odds of any mood or any anxiety disorder as a function of age, gender, marital status, urbanicity and employment using a multigroup approach $(n=35500)$. This allowed for the testing of specific lifespan hypotheses across participating countries.

Results. No simple geographical pattern exists with which to describe the relationship between 12-month prevalence of mood and anxiety disorders and age. Of the adults sampled, very few aged $\geqslant 80$ years met DSM-IV diagnostic criteria for these disorders. The associations between these disorders and key sociodemographic variables were relatively homogeneous across countries after adjusting for age.

Conclusions. Further research is required to confirm that there are indeed stages in the lifespan where the reported prevalence of mental disorders is low, such as among younger adults in the East and older adults in the West. This project illustrates the difficulties in conducting research among different age groups simultaneously.

Received 19 December 2012; Revised 13 April 2013; Accepted 18 April 2013; First published online 31 May 2013

Key words: Ageing, anxiety disorders, CIDI, Europe, mood disorders, multigroup.

\section{Introduction}

The nature of the relationship between the prevalence of mental disorders and age according to standardized diagnostic instruments such as the CIDI (Kessler \& Üstün, 2004) continues to generate debate. Studies conducted among community-dwelling adults have often

* Address for correspondence: Mr R. D. McDowell, Institute of Nursing and Health Research, School of Nursing, University of Ulster, Cromore Road, Coleraine, Co. Londonderry BT52 1SA, Northern Ireland, UK

(Email: McDowell-R3@email.ulster.ac.uk) reported relatively low levels of mood and anxiety disorders among the oldest adults surveyed in Western Europe (Alonso et al. 2004b), North America (Kessler et al. 2010) and Australasia (Andrews et al. 2001), although the same trend has not always been identified in Eastern Europe (Bromet et al. 2005). Consequently, some authors suggest that mental disorders are relatively uncommon in later life, attributable to factors such as an increased ability to deal with negative life experiences and greater emotional resilience and stability (Ernst \& Angst, 1995). Other commentators assert that this conclusion is erroneous and does not correspond with the experience of 
the medical profession (Snowdon, 2001; O'Connor, 2006).

The literature identifies several areas that could potentially distort the results obtained from communitybased surveys in an age-related way, namely design, measurement and analysis. Design issues include the inability of cross-sectional studies to tease out ageing from cohort effects, along with when, where and among whom the study took place. Measurement issues are concerned with how the quality of the data obtained from participants could be affected by age, such as deteriorating memory (Rogler et al. 1992), lack of understanding (Wetherell et al. 2009) and stigma (Aromaa et al. 2011), resulting in unintentional or deliberate under-reporting of mental illness among older adults (Woodal et al. 2010). They also concern the suitability of the instrument and outcome measures used across the lifespan (Fuentes \& Cox, 1997). Analysis issues include the inclusion or omission of control variables and the categorization of continuous variables such as age, as this has the potential at best to obscure detail and at worst to lead to residual confounding (Weinberg, 1995; MacCallum et al. 2002). For these reasons, studies of mental illness that are restricted to older adults sometimes use instruments specifically designed for use with this age group, such as the Geriatric Mental State-Automated Geriatric Examination for Computer Assisted Taxonomy (GMSAGECAT; Copeland et al. 1986). These instruments focus on current morbidity rather than lifetime recall and sometimes report higher levels of mental illness among older adults than those generated using the CIDI (Newman et al. 1998; Schaub et al. 2003) and a constant association between age and mental illness in later life (McDougall et al. 2007; Guerra et al. 2009; Prina et al. 2011).

Issues relating to age and mental illness are highly relevant to the European Union (EU) with its growing and ageing population (Giannakouris, 2008), and for whom $38.2 \%$ of the population ( 164.8 million people) are estimated to suffer from some form of mental disorder within a 12-month period (Wittchen et al. 2011). Although the body of cross-national literature examining the association between age and mental illness is considerable, the majority comprises systematic reviews (Riedel-Heller et al. 2006), meta-analyses (Wittchen et al. 2011), pooled analyses (Scott et al. 2008) or results obtained from analysing each country independently (Bromet et al. 2011). Examples of hierarchical modelling that allow for comparisons between countries to be made along the lifespan exist, but these tend to be limited to measures derived from symptom scales (Van de Velde et al. 2010). Consequently, the focus of this study was twofold: methodological and epidemiological. From a methodological perspective we wished to explore the use of multigroup methods to simultaneously model the 12 -month prevalence of mood and anxiety disorders across the adult lifespan in the 10 EU countries participating in the World Mental Health Survey Initiative (EU-WMH). These methods are often used when working within a latent variable framework but their potential to provide parsimonious solutions to the modelling of observed data has not been fully explored, at least within crossnational psychiatric epidemiology. From an epidemiological perspective there were three issues we wished to explore: first, whether the low levels of mental disorders reported among older adults are relatively uniform in later life; second, whether there is a geographical pattern to summarize the relationship between the prevalence of mental disorders and age across the EU; and third, whether the effects associated with well-known risk factors and correlates of mental disorders such as gender (Kessler, 2006), marital status (Rotermann, 2007; Gibb et al. 2011) and employment status (Honkonen et al. 2007) are relatively homogeneous between countries and across the lifespan.

\section{Method}

The 10 countries participating in the EU-WMH project are Belgium, Bulgaria, France, Germany, Italy, Northern Ireland, The Netherlands, Portugal, Romania and Spain. The design and methods used in these studies have been documented extensively elsewhere (Alonso et al. 2004a; Ferry et al. 2008; Tomov et al. 2008; Florescu et al. 2009) and are only outlined here.

\section{Selection of participants}

Each country implemented a stratified multistage random sample without replacement strategy to select participants with the sampling frame and number of sampling stages used varying between countries. There were a total of 37289 participants aged $\geqslant 18$ years across the 10 countries, with sample sizes ranging from 2357 in Romania to 5473 in Spain. Response rates varied from $45.9 \%$ in France to $78.6 \%$ in Spain, with an overall response rate of $63.4 \%$. Adults living in institutions were excluded. Interviews were conducted between 2001 and 2009. Data on the characteristics of the non-respondents were unavailable.

\section{Instrument}

Each country used the CIDI version 3.0 (Kessler \& Üstün, 2004), a fully standardized lay-administered diagnostic interview that generates diagnoses of mental disorders based on self-report and also obtains information such as sociodemographic variables and 
use of services. The CIDI is divided into two parts, with Part 1 assessing the core mental disorders, and it is these that are addressed in this study. Part 2 assesses other disorders among participants who meet the lifetime diagnostic criteria for any Part 1 disorder plus a random sample of all others. The CIDI has been validated with the SCID (First et al. 1995) in the USA, France, Italy and Spain, although the age distributions of these participants have not been reported (Kessler et al. 2004; Haro et al. 2006).

\section{Diagnostic criteria}

DSM-IV diagnostic criteria (APA, 1994) were used. A diagnosis of 'any mood disorder' was given to respondents who satisfied the diagnostic criteria for at least one of major depressive episode (MDE) and dysthymia (DYS). Mania was excluded as it was only assessed in Bulgaria, Northern Ireland, Portugal and Romania. A diagnosis of 'any anxiety disorder' was given to participants who satisfied the diagnostic criteria for at least one of generalized anxiety disorder (GAD), social phobia (SO), specific phobia (SP), panic disorder (PD) and agoraphobia (AGO) with or without panic. Organic exclusion rules were imposed in the formulation of all diagnoses, and diagnoses without hierarchy were used to allow for consideration of psychiatric co-morbidity.

\section{Other variables}

In addition to age (years) and country, we incorporated gender, marital status, urbanicity and employment status into our analyses. Because employment status was only assessed in Part 2 of the CIDI in Portugal, this necessitated using their Part 2 sample $(n=2060)$, giving a total of 35500 participants. It was not possible to include further variables without using the Part 2 sample in additional countries or removing some countries entirely from the analyses.

\section{Statistical analysis}

\section{The multigroup approach}

Multigroup methods comprise a common and convenient strategy for comparing models that incorporate latent variables in different populations but have not yet been fully explored for modelling the crossnational period prevalence of mood and anxiety disorders. Modelling was conducted in three stages: unadjusted models, where age was the only predictor of mental disorder; adjusted models, where other covariates were added; and models that incorporated interactions between age and the other variables that were of statistical significance. At each stage we modified models on the basis of measures such as the information criteria, the modification index (MI) and the associated expected parameter change (EPC). To facilitate comparisons between predictor variables measured on different scales, the EPCs were YX standardized (STDYX-EPC) by multiplying each EPC by its standard error (s.E.) as calculated across the entire sample (Greenland et al. 1991) and dividing by the S.E. of the fitted values again calculated across the entire sample. Differences between models in the latter were negligible. We also considered whether there was sufficient statistical power to detect misspecifications of size 0.1 in the STDYX-EPC and based model modification on the associated guidelines reported in the literature (Saris et al. 2009). MIs were determined to be large in respect of their relative size to each other (Byrne, 2011), with a fully standardized EPC considered to be large if it was approximately 0.2 or greater (Saris et al. 2009). Preliminary country-specific analyses showed that a second-degree polynomial for age would be a satisfactory functional form of age in most instances, hence logistic regression analyses were limited to quadratic models in an attempt to control for wave effects at either extreme of the age distribution and the potential for anomalous results that can arise when incorporating unnecessary higherorder terms (Aiken \& West, 1991). Age was centred to reduce collinearity and aid interpretation.

\section{Other details}

All descriptive and modelling analyses took account of the survey design using the appropriate weighting and stratification measures (Alonso et al. 2004a). Standard errors of the descriptive statistics were estimated using the Taylor series method (Wolter, 2007). Pooled Part 1 weights were used to generate descriptive statistics for the EU-WMH region as a whole, with country-specific Part 1 weights used for the multigroup analyses in all countries except Portugal. MLR estimation was used to generate estimates on the odds scale. Only univariate model modifications were considered because multivariate MIs (Kaplan \& Wenger, 1993) are not available in M-plus (Muthén \& Muthén, 1998-2013). We considered whether the lower numbers of older adults surveyed distorted our results by examining influence values (Cook \& Weisberg, 1982) and standardized Pearson residuals (Weng, 2010), and also through sensitivity analysis, but their inclusion made no substantive impact on the results and hence all participants were retained (for further details see Supplementary Figs A1, A2, and Supplementary Tables A1, A2). The results are held to be significant if they refer to statistical significance on a two-sided design-based test evaluated at the $5 \%$ level. The analyses were performed using 
M-Plus 6.2 (Muthén \& Muthén, 1998-2013) and Stata 11 SE (StataCorp, 2009); J-Rule (van der Veld et al. 2008; Oberski, 2009) was used to calculate the power values.

\section{Results}

\section{Descriptive statistics}

Table 1 details the 12-month prevalence of DSM-IV/ CIDI mood and anxiety disorders across the EU$\mathrm{WMH}$ region; $4.2 \%$ and $7.8 \%$ of participants were diagnosed as having at least one mood or anxiety disorder respectively within the past 12 months. The most prevalent mood disorder in each country was MDE, with prevalence varying from $1.8 \%$ (s.E. $=0.3$ ) in Romania to $8.9 \%$ (s.E. $=0.5$ ) in Northern Ireland. The most prevalent anxiety disorder in each country was SP, with the 12-month prevalence varying from $3.3 \%$ (S.E. $=0.4$ ) in Romania to $8.6 \%$ (S.E. $=0.5$ ) in Portugal. Northern Ireland and Portugal had the highest levels of all mood and anxiety disorders.

Figure $1 a$ plots the unweighted log odds of any 12-month mood disorder across the adult lifespan for selected countries (see online Supplementary Fig. A3 for $\log$ odds for all 10 countries), restricted to ages where there were at least 20 participants to minimize wave effects at the upper end of the age distribution. Although the log odds of any mood disorder varies widely with age and country, levels converge in later life. Of note is the relatively high log odds of any 12-month mood disorder in Northern Ireland for most of the adult life, and a steady increase in the log odds of any mood disorder with age in Bulgaria. In all countries apart from Bulgaria, the log odds of any 12-month anxiety disorder declines with age (with particularly high levels among younger Portuguese adults; Fig. $1 b$ and online Supplementary Fig. A4).

Table 2 details sampling and disorder levels among adults aged $\geqslant 80$ years, data that we were not able to fully incorporate into the plots. Levels of mood and anxiety disorders among these adults are approximately half those of all adults. With the exception of Portugal (whose oldest participants were 81 years), a maximum of $2.8 \%$ of participants over the age of 80 years satisfied the diagnostic criteria for any 12-month mood disorder in Western European countries, whereas in Bulgaria and Romania the percentages were higher $(4.3 \%$ and $7.1 \%$ respectively). Those over 80 years who met the diagnostic criteria tended to be younger rather than older.

\section{Any mood disorder}

The steps for model fitting and the rationale for model modification at each step are detailed in Table 3, with the results listed in Tables 4 and 5. In the majority of countries prevalence is lowest among the oldest adults but it is only possible to estimate a non-zero odds of a disorder up to the maximum age at which the diagnostic criteria are met. In Belgium, France, Germany and The Netherlands, the odds of any 12-month mood disorder declines steadily for most, if not all, of the adult lifespan. Although the odds of any mood disorder is also lowest among the oldest adults in Northern Ireland, Portugal and Spain, there is a notable peak in Northern Ireland and Portugal at 38 years, and at 51 years in Spain. In Bulgaria and Romania, prevalence increases with age whereas in Italy prevalence declines with age until 43 years, at which point it increases. Prevalence increases with age in Italy along the entire lifespan after the relevant adjustments are made.

The effects associated with gender, marital status, urbanicity and employment on any 12-month mood disorder are relatively homogeneous across countries after taking account of the differential effects of ageing. The odds of any 12-month mood disorder are more than twice as high in females as in males [odds ratio (OR) 2.1, 95\% confidence interval (CI) 1.8-2.4, $p<0.001$ ], with urban living relative to rural living associated with an increased odds of any 12-month mood disorder (OR 1.2, 95\% CI 1.0-1.5, $p=0.02$ ). Being divorced or never married as opposed to being married or in a marriage-like relationship is also associated with an increased odds of any 12-month mood disorder for an individual of average age (46.9 years) (OR 2.3, 95\% CI 1.9-2.7, $p<0.001$ and OR 1.3, $95 \%$ CI 1.1-1.6, $p=0.01$ respectively). The effect of divorce is associated with a fall in the odds of any 12 -month mood disorder of $2 \%$ annually $(p=0.001)$ in each country apart from Portugal, where there is borderline evidence of an increasing effect with age of $2 \%$ annually $(p=0.07)$. An individual of average age is nearly three times as likely to have any 12-month mood disorder if they are unemployed rather than employed (OR 2.7, 95\% CI 2.3-3.2, $p<0.001)$. The interaction of employment status with age (Satorra-Bentler test, $p=0.01$ ) seems to have been driven by the declining effect associated with retirement on mood disorders with age; this is not surprising given that most retired adults are older rather than younger.

\section{Any anxiety disorder}

In Spain and Portugal the odds of any 12-month anxiety disorder declines steadily with age; in all other countries with the exception of Bulgaria, it peaks between the ages of 27 and 39 years. In Bulgaria the prevalence of any 12-month anxiety disorder increases with age until 67 years, and only 
Table 1. Unadjusted 12-month prevalence of mood and anxiety disorders (without hierarchy): the EU-WMH project

\begin{tabular}{|c|c|c|c|c|c|c|c|c|c|}
\hline \multirow[b]{2}{*}{ Disorder } & \multicolumn{3}{|c|}{$\begin{array}{l}\text { Belgium }^{a} \\
(n=2419)\end{array}$} & \multicolumn{2}{|c|}{$\begin{array}{l}\text { Bulgaria }^{\text {a }} \\
(n=5318)\end{array}$} & \multicolumn{2}{|c|}{$\begin{array}{l}\text { France }^{\mathrm{a}} \\
(n=2894)\end{array}$} & \multicolumn{2}{|c|}{$\begin{array}{l}\text { Germany }^{\mathrm{a}} \\
(n=3555)\end{array}$} \\
\hline & $n$ & \multicolumn{2}{|c|}{$\%$ (S.E.) } & $n$ & $\%$ (S.E.) & $n$ & \% (S.E.) & $n$ & $\%$ (S.E.) \\
\hline Major depressive episode & \multicolumn{2}{|l|}{113} & $4.97(0.56)$ & 148 & $2.52(0.25)$ & 172 & $5.87(0.54)$ & 109 & $3.00(0.33)$ \\
\hline Dysthymia $^{c}$ & \multicolumn{2}{|l|}{13} & $0.52(0.19)$ & 51 & $0.92(0.16)$ & 19 & $0.60(0.17)$ & 13 & $0.37(0.13)$ \\
\hline At least one mood disorder & \multicolumn{2}{|l|}{123} & $5.40(0.59)$ & 155 & $2.69(0.26)$ & 190 & $6.45(0.56)$ & 120 & $3.32(0.35)$ \\
\hline Panic disorder & \multicolumn{2}{|l|}{19} & $0.88(0.24)$ & 34 & $0.57(0.11)$ & 23 & $0.95(0.25)$ & 28 & $0.74(0.16)$ \\
\hline Agoraphobia with/without panic & \multicolumn{2}{|l|}{12} & $0.63(0.22)$ & 5 & $0.11(0.05)$ & 30 & $1.04(0.24)$ & 17 & $0.54(0.15)$ \\
\hline Specific phobia & \multicolumn{2}{|l|}{117} & $5.00(0.55)$ & 218 & $3.93(0.30)$ & 226 & $7.65(0.60)$ & 248 & $6.85(0.48)$ \\
\hline Social phobia & \multicolumn{2}{|l|}{28} & $1.21(0.29)$ & 27 & $0.62(0.14)$ & 72 & $2.55(0.38)$ & 58 & $1.51(0.23)$ \\
\hline Generalized anxiety disorder & \multicolumn{2}{|l|}{27} & $0.86(0.19)$ & 57 & $1.15(0.18)$ & 61 & $2.08(0.33)$ & 22 & $0.53(0.13)$ \\
\hline At least one anxiety disorder & \multicolumn{2}{|l|}{173} & $7.19(0.64)$ & 300 & $5.61(0.37)$ & 331 & $11.28(0.72)$ & 312 & $8.56(0.53)$ \\
\hline \multirow[t]{2}{*}{ At least one mood or anxiety disorder } & 255 & & $0.79)$ & 408 & $7.45(0.42)$ & 448 & $15.36(0.83)$ & 377 & $10.25(0.57)$ \\
\hline & $\begin{array}{l}\text { Italy }^{\mathrm{a}} \\
(n=47\end{array}$ & & & $\begin{array}{l}\text { The }) \\
(n=23\end{array}$ & herlands ${ }^{\mathrm{a}}$ & $\begin{array}{l}\text { Nortl } \\
(n=43\end{array}$ & Ireland ${ }^{\mathrm{a}}$ & $\begin{array}{l}\text { Port } \\
(n=3\end{array}$ & \\
\hline Disorder & $n$ & & & $n$ & $\%$ (S.E.) & $n$ & $\%$ (S.E.) & $n$ & $\%$ (S.E.) \\
\hline Major depressive episode & 129 & & & 135 & $4.88(0.54)$ & 434 & $8.92(0.48)$ & 320 & $7.39(0.44)$ \\
\hline Dysthymia $^{c}$ & 18 & & 10) & 11 & $0.44(0.16)$ & 107 & $2.09(0.23)$ & 85 & $1.98(0.24)$ \\
\hline At least one mood disorder & 145 & & 29) & 142 & $5.12(0.55)$ & 446 & $9.22(0.49)$ & 326 & $7.50(0.44)$ \\
\hline Panic disorder & 30 & & .12) & 29 & $1.25(0.28)$ & 114 & $2.33(0.26)$ & 32 & $0.91(0.17)$ \\
\hline Agoraphobia with/without panic & 25 & & 14) & 14 & $0.73(0.24)$ & 99 & $1.95(0.22)$ & 44 & $0.92(0.15)$ \\
\hline Specific phobia & 181 & & & 135 & $5.39(0.55)$ & 336 & $7.19(0.44)$ & 370 & $8.64(0.48)$ \\
\hline Social phobia & 53 & & .16) & 30 & $1.32(0.31)$ & 183 & $3.96(0.33)$ & 124 & $3.14(0.30)$ \\
\hline Generalized anxiety disorder & 28 & & & 28 & $1.02(0.22)$ & 150 & $2.84(0.27)$ & 145 & $3.25(0.29)$ \\
\hline At least one anxiety disorder & 268 & & 36) & 203 & $8.30(0.70)$ & 581 & $12.25(0.56)$ & 567 & $13.69(0.59)$ \\
\hline At least one mood or anxiety disorder & 358 & & 42) & 298 & $11.5(0.80)$ & 796 & $16.7(0.64)$ & 739 & $17.63(0.66)$ \\
\hline & & $\begin{array}{l}\text { Rom } \\
(n=23\end{array}$ & & & $\begin{array}{l}\text { Spain }^{\mathrm{a}} \\
(n=5473)\end{array}$ & & & $\begin{array}{l}\text { All }^{\mathrm{b}} \\
(n=37289)\end{array}$ & \\
\hline Disorder & & $n$ & $\%($ & & $n$ & $\%(\mathrm{~s}$. & & $n$ & \% (S.E.) \\
\hline Major depressive episode & & 16 & 1.8 & 0.31) & 247 & 3.99 & & 1850 & $3.88(0.15)$ \\
\hline Dysthymia $^{c}$ & & 17 & 0.5 & $0.15)$ & 22 & 0.40 & & 356 & $0.53(0.05)$ \\
\hline At least one mood disorder & & 19 & 1.8 & 0.31) & 268 & 4.37 & & 1964 & $4.22(0.16)$ \\
\hline Panic disorder & & 10 & 0.4 & $0.17)$ & 45 & 0.60 & & 364 & $0.76(0.07)$ \\
\hline Agoraphobia with/without panic & & 8 & 0.5 & 0.20) & 30 & 0.52 & & 284 & $0.66(0.07)$ \\
\hline Specific phobia & & 32 & 3.2 & $0.42)$ & 206 & 3.83 & & 2119 & $5.59(0.19)$ \\
\hline Social phobia & & 22 & 1.0 & $0.25)$ & 33 & 0.66 & & 630 & $1.49(0.10)$ \\
\hline Generalized anxiety disorder & & 9 & 0.2 & 0.10) & 59 & 0.83 & & 586 & $1.00(0.08)$ \\
\hline At least one anxiety disorder & & 6 & 4.18 & 0.47) & 321 & 5.69 & & 3162 & $7.84(0.22)$ \\
\hline At least one mood or anxiety disorder & & 37 & 5.4 & 0.53) & 495 & 8.56 & & 4311 & $10.4(0.24)$ \\
\hline
\end{tabular}

EU-WMH, European Union World Mental Health; $n$, number of cases (unweighted);\%, percentage of cases (weighted); s.E., standard error.

a Part 1 country specific weights.

${ }^{\mathrm{b}}$ Part 1 pooled sample weights.

${ }^{\mathrm{c}}$ Six countries (Belgium, France, Germany, Italy, The Netherlands, Spain) completed a specialized Dysthymia module.

The prevalence reported here is that generated from the Depression module as completed by all 10 countries. 

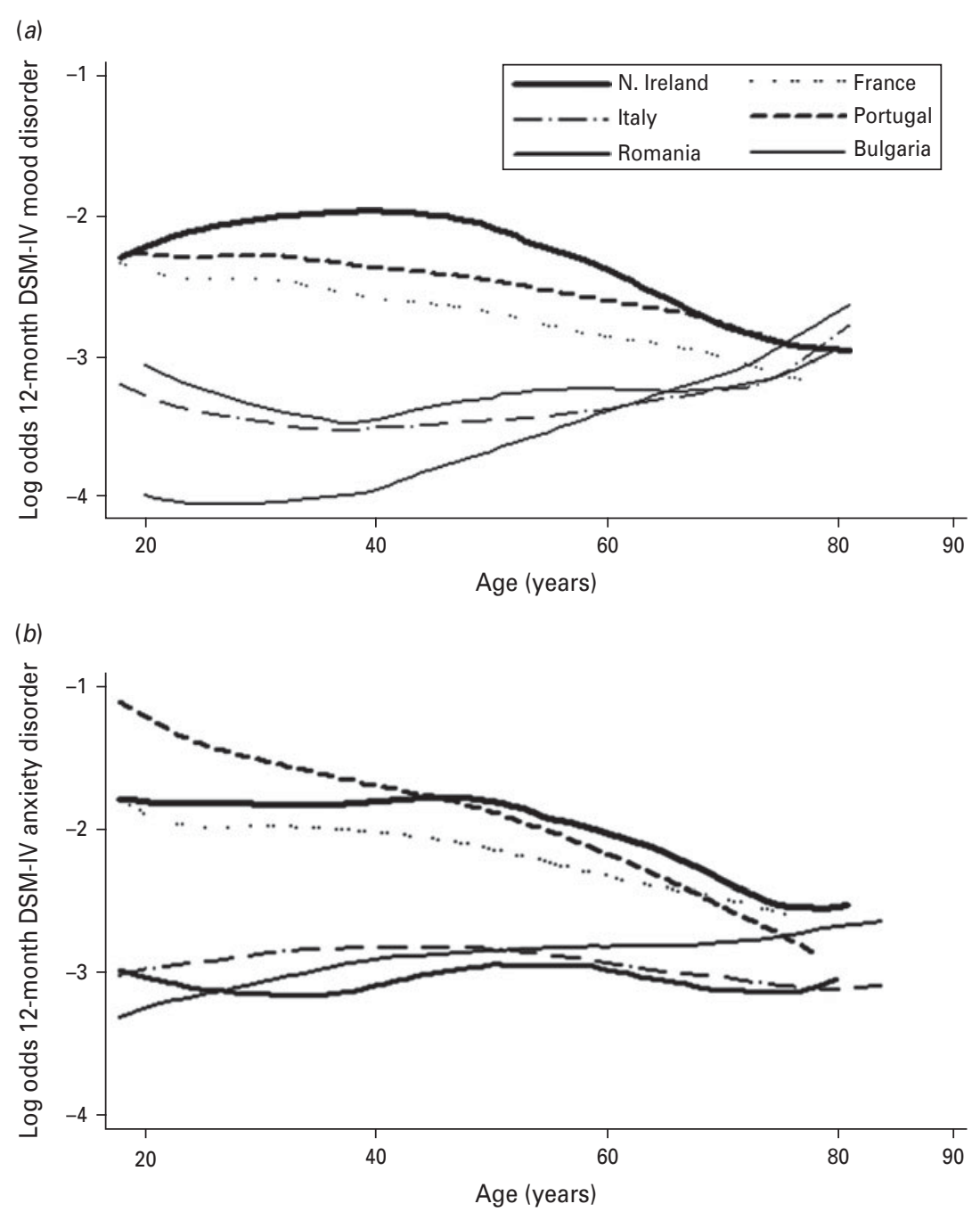

Fig. 1. Log odds 12-month Part 1 DSM-IV (a) mood disorder (without hierarchy) and $(b)$ anxiety disorder (without hierarchy) by age.

declines slightly thereafter. Levels of anxiety disorders are particularly high among the youngest adults in both Portugal and Belgium when the relevant adjustments are made.

The effects associated with gender, marital status, urbanicity and employment on any 12-month anxiety disorder are relatively homogeneous across countries after taking account of the differential effects of ageing. Being divorced relative to being married is associated with an increase in the odds of any anxiety disorder of $23 \%$ (OR 1.2, 95\% CI 1.1-1.4, $p=0.003$ ), and female gender is associated with an increase in the odds of any 12-month anxiety disorder of $160 \%$ (OR 2.6, 95\% CI 2.3-2.9, $p<0.001$ ) in all countries except Belgium, where there is no significant gender effect (OR 1.2, $95 \%$ CI 0.8-1.8, $p=0.3$ ). In Belgium, living in a midsize area relative to a rural area is associated with a reduction in the odds of any 12-month anxiety disorder by almost $50 \%$ for an individual of average age (OR 0.5, 95\% CI 0.4-0.8, $p=0.002$ ). The effect of city living instead of rural living is associated with an increase in the odds of a 12-month anxiety disorder by $4 \%$ annually in Romania (OR 1.0, 95\% CI 1.0-1.1, $p$ $=0.001)$. An individual of average age is nearly twice as likely to have a 12-month anxiety disorder if they are unemployed rather than employed (OR 1.9, 95\% CI 1.6-2.3, $p<0.001)$.

\section{Discussion}

\section{Methodological discussion}

This study used a multigroup strategy to explore the relationship between age and mental disorders in a cross-national context. Multigroup analysis is a useful modelling strategy when the number of groups is 
Table 2. Number of participants aged $\geqslant 80$ years diagnosed with 12-month mood or anxiety disorder (without hierarchy): the EU-WMH project

\begin{tabular}{|c|c|c|c|c|c|c|}
\hline Country & $\begin{array}{l}\text { Maximum } \\
\text { age } \\
\text { interviewed } \\
\text { (years) }\end{array}$ & $\begin{array}{l}\text { No. of } \\
\text { participants } \\
\text { aged } \geqslant 80 \\
\text { years }\end{array}$ & $\begin{array}{l}\text { No. (weighted } \%^{\mathrm{a}} \text { ) } \\
\text { of adults aged } \\
\geqslant 80 \text { years } \\
\text { diagnosed with } \\
\text { any DSM-IV mood } \\
\text { disorder (Part } 1 \text { ) }\end{array}$ & $\begin{array}{l}\text { Age (years) of } \\
\text { those } \geqslant 80 \text { years } \\
\text { who satisfy } \\
\text { DSM-IV mood } \\
\text { disorder (Part } 1)^{b}\end{array}$ & $\begin{array}{l}\text { No. (weighted } \%{ }^{\mathrm{a}} \text { ) } \\
\text { of adults aged } \geqslant 80 \\
\text { years diagnosed with } \\
\text { any DSM-IV anxiety } \\
\text { disorder (Part } 1 \text { ) }\end{array}$ & $\begin{array}{l}\text { Age (years) of } \\
\text { those } \geqslant 80 \text { years } \\
\text { who satisfy } \\
\text { DSM-IV anxiety } \\
\text { disorder (Part } 1)^{b}\end{array}$ \\
\hline Belgium & 95 & 82 & 0 & - & $2(2.17)$ & 82,86 \\
\hline Bulgaria & 98 & 196 & $11(7.11)$ & $6(80), 3(81), 2(85)$ & $14(9.62)$ & $\begin{array}{c}8(80), 2(83), 84, \\
2(85), 87\end{array}$ \\
\hline France & 97 & 63 & $1(2.13)$ & 83 & $3(3.92)$ & $81,84,91$ \\
\hline Germany & 95 & 99 & $2(2.17)$ & 80,89 & $2(2.86)$ & 80,85 \\
\hline Italy & 100 & 137 & $4(2.78)$ & $81,84,87,91$ & $6(5.05)$ & $\begin{array}{l}80,81,84,87 \\
89,91\end{array}$ \\
\hline $\begin{array}{l}\text { The } \\
\text { Netherlands }\end{array}$ & 95 & 79 & 0 & - & $5(6.20)$ & $80,2(81), 83,85$ \\
\hline $\begin{array}{l}\text { Northern } \\
\text { Ireland }\end{array}$ & 97 & 164 & $2(1.99)$ & $2(81)$ & $2(2.04)$ & $2(81)$ \\
\hline Portugal & 81 & 9 & $2(25.61)$ & $2(80)$ & 1 (12.6) & 80 \\
\hline Romania & 96 & 95 & $4(4.25)$ & $2(80), 82,96$ & $6(4.60)$ & $\begin{array}{r}80,81,82 \\
2(83), 85\end{array}$ \\
\hline Spain & 98 & 270 & $9(2.24)$ & $\begin{array}{l}3(80), 3(81), 82 \\
84,85\end{array}$ & $17(6.28)$ & $\begin{array}{l}7(80), 2(82), 83 \\
2(84), 85,2(86), \\
2(89)\end{array}$ \\
\hline
\end{tabular}

EU-WMH, European Union World Mental Health.

a Part 1 country-specific weights.

b 2 (80) means two participants aged 80 years, etc.

relatively small (e.g. $\leqslant 20)$ and the researcher is interested in exploring specific differences between countries (Selig et al. 2008), whereas hierarchical modelling can be used when the number of groups is larger and knowledge of specific differences between groups is of lesser importance (Bou \& Satorra, 2010).

We are aware of several limitations to our analyses. The use of cross-sectional data does not allow for the distinction between ageing and cohort effects. Diagnostic measures have been based on retrospective self-report, which may lead to an underestimation of the levels of mood and anxiety disorders in later life. Diagnostic criteria are invariant with age and whether this is appropriate is debated (Jeste et al. 2007). We grouped the disorders according to the DSM-IV metastructure but other combinations are possible. The number of sociodemographic variables included is relatively small because of the lack of comparable data collected from the Part 1 samples in the different countries.

Although we set out in advance criteria that guided the extent to which model modification would be permitted, there is the possibility of overfitting or underfitting when using a structural equation modelling approach because of sampling error (Green \&
Babyak, 1997). This could be explored further using techniques such as cross-validation. Treating age as a continuous variable helped us to explore the effects associated with age in detail, in addition to when to stop extrapolating results. Being able to estimate residuals and influence values meant we were satisfied to report results from models fitted across the entire age distribution of the sample.

\section{Epidemiological discussion}

Low numbers of older adults meeting 12-month DSM-IVI CIDI diagnostic criteria for mood and anxiety disorders

It is relatively uncommon for adults aged over 80 years to meet DSM-IV diagnostic criteria for mood disorders, and to a certain degree anxiety disorders, in each country despite the modest number of adults sampled above this age. Consequently, some argue that this observation, in conjunction with the general decline in the prevalence of mood and anxiety disorders with age noted in the majority of countries, mirrors reality and that the oldest community-dwelling adults rarely, if ever, experience depression or anxiety in any 12-month period. Theories of stress-related growth are 
Table 3. Modelling the log odds of a diagnosis of any 12-month mood and anxiety disorder (without hierarchy): the EU-WMH project

\begin{tabular}{|c|c|c|c|c|c|c|c|c|c|c|}
\hline Model & Description & $\begin{array}{l}\text { No. of } \\
\text { participants }\end{array}$ & $\begin{array}{l}\text { Log } \\
\text { likelihood }\end{array}$ & $\begin{array}{l}\text { No. of free } \\
\text { parameters }\end{array}$ & AIC & BIC & SSA-BIC & H-L test & $\begin{array}{l}\text { SB test: null } \\
\text { model } v . \\
\text { alternative } \\
\text { model }\end{array}$ & Comments \\
\hline \multicolumn{11}{|c|}{ Any mood disorder } \\
\hline M1 & $\begin{array}{l}\text { Age and age }{ }^{2} \text { all estimated freely } \\
\text { in each country }\end{array}$ & 35500 & -86146.70 & 39 & 172371.40 & 172702.02 & 172578.07 & $\begin{array}{l}F_{9,35382} \\
\quad=0.96 \\
p=0.47\end{array}$ & - & $\begin{array}{l}\text { Coefficients for }(\text { age })^{2} \text { statistically } \\
\text { significant in Northern Ireland } \\
(p<0.001), \text { Spain }(p=0.004) \text { and } \\
\text { Portugal }(p=0.01)\end{array}$ \\
\hline M2 & $\begin{array}{l}\text { Constrain effect of age to be } \\
\text { equal across all } 10 \text { countries } \\
\text { and age }^{2} \text { to be equal in } \\
\text { Northern Ireland, Spain and } \\
\text { Portugal }\end{array}$ & 35500 & -86193.70 & 28 & 172443.40 & 172680.76 & 172591.78 & $\begin{array}{l}F_{9,35382} \\
=1.39 \\
p=0.18\end{array}$ & $\begin{array}{l}\mathrm{M} 2 v . \mathrm{M} 1: \\
p<0.001\end{array}$ & $\begin{array}{l}\text { No obvious pattern, MIs range from } \\
0.09 \text { to } 44.86\end{array}$ \\
\hline M3 & $\begin{array}{l}\text { As M2 but constrain effect of age } \\
\text { to be the same in Romania and } \\
\text { Bulgaria separately from other } \\
\text { eight countries }\end{array}$ & 35500 & -86167.09 & 29 & 172392.17 & 172638.02 & 172545.85 & $\begin{array}{l}F_{9,35382} \\
\quad=1.14 \\
p=0.33\end{array}$ & $\begin{array}{l}\text { M2 v. M3: } \\
p<0.001\end{array}$ & $\begin{array}{l}\text { One notably large MI associated with } \\
\text { constraint on age in Spain (MI 19.23, } \\
\text { STDYX-EPC 0.24, power 0.43) }\end{array}$ \\
\hline M4 & $\begin{array}{l}\text { As M3 but estimate age freely in } \\
\text { Spain }\end{array}$ & 35500 & -86157.71 & 30 & 172375.42 & 172629.74 & 172534.40 & $\begin{array}{l}F_{9,35382} \\
\quad=1.31 \\
p=0.23\end{array}$ & $\begin{array}{c}\text { M3 v. M4: } \\
p<0.001\end{array}$ & $\begin{array}{l}\text { One relatively large MI associated } \\
\text { with constraint on age in Italy } \\
\text { (MI } 12.67, \text { STDYX-EPC } 0.20 \text {, } \\
\text { power } 0.42)\end{array}$ \\
\hline M5 & $\begin{array}{l}\text { As M4 but estimate age freely in } \\
\text { Italy }\end{array}$ & 35500 & -86151.23 & 31 & 172364.46 & 172627.26 & 172528.74 & $\begin{array}{l}F_{9,35382} \\
=0.93 \\
p=0.50\end{array}$ & $\begin{array}{c}\text { M4 v. M5: } \\
p=0.003\end{array}$ & $\begin{array}{l}\text { All } \mathrm{MI}<3.62 ; \text { no further } \\
\text { modifications necessary }\end{array}$ \\
\hline M6 & $\begin{array}{l}\text { As M5, add and constrain effects } \\
\text { associated with gender, marital } \\
\text { status, urbanicity and } \\
\text { employment to be the same } \\
\text { across countries }\end{array}$ & $35495^{\mathrm{a}}$ & -85882.05 & 40 & 171844.10 & 172183.19 & 172056.00 & $\begin{array}{l}F_{9,35377} \\
\quad=0.49 \\
p=0.88\end{array}$ & $\begin{array}{c}\text { M5 v. M6: } \\
p<0.001\end{array}$ & $\begin{array}{l}\text { No notably large MIs; no } \\
\text { modifications made }\end{array}$ \\
\hline M7 & $\begin{array}{l}\text { As M6, add interaction by age } \\
\text { (linear) for each control } \\
\text { variable }\end{array}$ & $35495^{\mathrm{a}}$ & -85866.54 & 49 & 171831.08 & 172246.46 & 172090.73 & $\begin{array}{l}F_{9,35377} \\
\quad=1.02 \\
p=0.42\end{array}$ & $\begin{array}{l}\text { M6 v. M7: } \\
p=0.004\end{array}$ & $\begin{array}{l}\text { Comparison of nested models } \\
\text { allowed for the removal of } \\
\text { interactions of age with gender } \\
(p=1.00) \text { and urbanicity }(p=0.41)\end{array}$ \\
\hline M8 & $\begin{array}{l}\text { Retain interactions of age with } \\
\text { marital status }(p=0.01) \text { and } \\
\text { employment }(p=0.01)\end{array}$ & $35495^{\mathrm{a}}$ & -85867.76 & 46 & 171827.52 & 172217.47 & 172071.28 & $\begin{array}{l}F_{9,35377} \\
\quad=0.86 \\
p=0.56\end{array}$ & $\begin{array}{l}\text { M8 v. M7: } \\
p=0.63\end{array}$ & $\begin{array}{l}\text { One relatively large MI with large } \\
\text { STDYX-EPC: the varying effect with } \\
\text { age of divorce relative to marriage in } \\
\text { Portugal: MI } 10.50 \text { (STDYX-EPC } \\
0.27 \text {, power } 0.23 \text { ) }\end{array}$ \\
\hline
\end{tabular}


Any anxiety disorder

Age and age 2 all estimated freely 35500

A4 As A3, add and constrain effects 35500 associated with gender, marital status, urbanicity and employment to be the same across countries

A5 As A4 but freely estimate gender $35495^{\circ}$ effect in Belgium

midsized $v$. rural urbanicity in

\section{Belgium}

A7 As A6, add interaction by age for $35495^{\circ}$ each control variable urbanicity $(p=0.07)$ and

employment $(p=0.01)$

$\begin{array}{llll}\text { As A8, free interaction of city } & 35495^{\mathrm{a}} & -88826.38 & 48 \\ \text { relative to urban living with } & & & \end{array}$

$\begin{array}{llll}171820.48 & 172218.91 & 172069.54 & F_{9,35}\end{array}$ $=1.21, \quad p=0.002$ $p=0.29$ modifications made

Coefficients for age $\mathrm{e}^{2}$ of significance in Northern Ireland $(p<0.001)$ and

Belgium (borderline, $p=0.07$ ) $=0.60$,

$p=0.80$

$178447.84 \quad 178693.68 \quad 178601.52 \quad F_{9,3}$ $=2.54, \quad p<0.001$

$p=0.01$

$\begin{array}{lllll}178413.01 & 178667.33 & 178572.99 & F_{9,35382} & \text { A2 v. A3: }\end{array}$ $=0.97, \quad p<0.001$ $p=0.46$

$-88862.21 \quad 39$

$\begin{array}{lllll}177802.42 & 178433.03 & 178009.09 & F_{9,35377} & \text { A3 v. A4 }\end{array}$ $=0.39, \quad p<0.001$ $p=0.94$

$\begin{array}{llll}177784.40 & 178123.49 & 177996.37 \quad F_{9}\end{array}$ 9,35377 $p=0.85$

177769.67

$F_{9,35377}$

A5 v. A6:

$=0.36, \quad p<0.001$

$p=0.95$

$-88830.65 \quad 50$

$\begin{array}{lllll}177761.29 & 178185.15 & 178026.25 & F_{9,35377} & \text { A6 v. A7: }\end{array}$ $=0.18, \quad p=0.017$ $p=1.00$

$177758.23 \quad 178156.65 \quad 178007.29$

$F_{9,35377}$ $=0.26$

A8 v. A7: $p=0.99$

A8 v. A9 $=0.30, \quad p=0.001$ $p=0.98$
One large MI associated with age in Bulgaria (MI 35.46, STDYX-EPC

0.28 , power 0.57 )

No notably large MI; no

modifications made

Three large MI, largest being female v. male gender in Belgium (MI 21.43 STDYX-EPC -0.30 , power 0.34 )

One large MI, mid-sized $v$. rural urbanicity in Belgium (MI 18.33, No notably large MI with large STDYX-EPC; no modifications made

Comparison of nested models allowed for the removal of interactions of age with gender $(p=1.00)$ and marital status $(p=0.32)$ Two relatively large MI, largest being relative to urban living in Romania (MI 11.47, STDYX-EPC 0.30, power $0.21)$

No notably large modifications with large STDYX-EPC; no further modifications STDYX-EPC -0.27 , power 0.34 ) varying effect with age of city

EU-WMH, European Union World Mental Health; AIC, Aikake information criteria; BIC, Bayesian information criteria; SSA-BIC, sample size-adjusted BIC; H-L test, Hosmer-Lemeshow test; S-B test, Satorra-Bentler scaled $\chi^{2}$ difference test; MI, modification index; STDYX-EPC, YX standardized expected parameter change.

${ }^{a}$ Five participants in Bulgaria had no urbanicity recorded. 
Table 4. Minimum and maximum odds of any mood and anxiety disorder with age of attainment by country: the EU-WMH project

\begin{tabular}{|c|c|c|c|c|}
\hline \multirow[b]{3}{*}{ Country } & \multicolumn{4}{|l|}{ Any mood disorder } \\
\hline & \multicolumn{2}{|l|}{ Unadjusted analysis } & \multicolumn{2}{|l|}{ Adjusted analysis $^{c}$} \\
\hline & $\begin{array}{l}\text { Minimum Odds }(95 \% \mathrm{CI}) \\
\text { (age in years) }\end{array}$ & $\begin{array}{l}\text { Maximum Odds }(95 \% \mathrm{CI}) \\
\text { (age in years) }\end{array}$ & $\begin{array}{l}\text { Minimum Odds }(95 \% \mathrm{CI}) \\
\text { (age in years) }\end{array}$ & $\begin{array}{l}\text { Maximum Odds }(95 \% \mathrm{CI}) \\
\text { (age in years) }\end{array}$ \\
\hline Belgium $^{a}$ & $0.03(0.01-0.05)(78)^{f}$ & $0.07(0.06-0.09)(28)$ & $0.01(0.004-0.03)(78)^{f}$ & $0.03(0.02-0.04)(37)$ \\
\hline Bulgaria $^{a}$ & $0.01(0.005-0.02)(18)^{\mathrm{e}}$ & $0.06(0.03-0.11)(85)^{\mathrm{f}}$ & $0.004(0.001-0.01)(18)^{\mathrm{e}}$ & $0.03(0.01-0.08)(85)^{\mathrm{f}}$ \\
\hline France $^{\mathrm{a}}$ & $0.04(0.02-0.07)(83)^{f}$ & $0.10(0.07-0.16)(18)^{\mathrm{e}}$ & $0.02(0.01-0.04)(83)^{\mathrm{f}}$ & $0.04(0.02-0.06)(19)$ \\
\hline Germany $^{\mathrm{a}}$ & $0.03(0.02-0.04)(74)$ & $0.06(0.04-0.09)(19)^{\mathrm{e}}$ & $0.01(0.01-0.02)(70)$ & $0.02(0.01-0.04)(19)^{\mathrm{e}}$ \\
\hline Italy $^{\mathrm{a}}$ & $0.03(0.02-0.04)(43)$ & $0.07(0.03-0.13)(91)^{f}$ & $0.01(0.01-0.02)(18)^{\mathrm{e}}$ & $0.03(0.01-0.09)(91)^{f}$ \\
\hline The Netherlands $^{\mathrm{a}}$ & $0.03(0.01-0.06)(79)^{\mathrm{f}}$ & $0.07(0.04-0.13)(21)$ & $0.01(0.005-0.04)(79)^{\mathrm{f}}$ & $0.03(0.02-0.04)(31)$ \\
\hline Northern Ireland ${ }^{\mathrm{a}}$ & $0.03(0.02-0.04)(81)^{\mathrm{f}}$ & $0.13(0.12-0.15)(38)$ & $0.01(0.005-0.03)(81)^{\mathrm{f}}$ & $0.06(0.05-0.07)(41)$ \\
\hline Portugal $^{\mathrm{b}}$ & $0.02(0.02-0.03)(80)^{\mathrm{f}}$ & $0.11(0.10-0.13)(38)$ & $0.01(0.006-0.02)(80)^{\mathrm{f}}$ & $0.05(0.04-0.06)(41)$ \\
\hline Romania $^{a}$ & $0.01(0.002-0.02)(18)^{\mathrm{e}}$ & $0.03(0.01-0.17)(89)$ & $0.002(0.001-0.01)(18)^{\mathrm{e}}$ & $0.02(0.002-0.31)(96)^{\mathrm{f}}$ \\
\hline Spain $^{\mathrm{a}}$ & $0.02(0.01-0.03)(85)^{f}$ & $0.06(0.05-0.07)(51)$ & $0.01(0.005-0.01)(18)^{\mathrm{e}}$ & $0.03(0.02-0.03)(53)$ \\
\hline
\end{tabular}

\begin{tabular}{|c|c|c|c|c|}
\hline \multirow[b]{3}{*}{ Country } & \multicolumn{4}{|l|}{ Any anxiety disorder } \\
\hline & \multicolumn{2}{|l|}{ Unadjusted } & \multicolumn{2}{|l|}{ Adjusted analysis ${ }^{\mathrm{d}}$} \\
\hline & $\begin{array}{l}\text { Minimum Odds }(95 \% \mathrm{CI}) \\
\text { (age in years) }\end{array}$ & $\begin{array}{l}\text { Maximum Odds }(95 \% \mathrm{CI}) \\
\text { (age in years) }\end{array}$ & $\begin{array}{l}\text { Minimum Odds }(95 \% \mathrm{CI}) \\
\text { (age in years) }\end{array}$ & $\begin{array}{l}\text { Maximum Odds }(95 \% \mathrm{CI}) \\
\text { (age in years) }\end{array}$ \\
\hline Belgium $^{a}$ & $0.03(0.02-0.04)(86)^{f}$ & $0.09(0.08-0.11)(39)$ & $0.03(0.01-0.07)(86)^{f}$ & $0.13(0.08-0.20)(29)$ \\
\hline Bulgaria $^{a}$ & $0.03(0.02-0.05)(18)^{\mathrm{e}}$ & $0.07(0.06-0.09)(67)$ & $0.02(0.01-0.03)(18)^{\mathrm{e}}$ & $0.03(0.02-0.04)(66)$ \\
\hline France $^{\mathrm{a}}$ & $0.06(0.03-0.14)(91)^{\mathrm{f}}$ & $0.15(0.12-0.18)(27)$ & $0.02(0.01-0.07)(91)^{\mathrm{f}}$ & $0.09(0.06-0.14)(18)^{\mathrm{e}}$ \\
\hline Germany $^{\mathrm{a}}$ & $0.04(0.02-0.08)(85)^{\mathrm{f}}$ & $0.11(0.10-0.13)(35)$ & $0.02(0.01-0.04)(85)^{\mathrm{f}}$ & $0.06(0.04-0.09)(19)^{\mathrm{e}}$ \\
\hline Italy $^{\mathrm{a}}$ & $0.03(0.01-0.06)(89)^{\mathrm{f}}$ & $0.07(0.06-0.08)(30)$ & $0.01(0.004-0.03)(89)^{\mathrm{f}}$ & $0.04(0.03-0.06)(20)$ \\
\hline The Netherlands ${ }^{a}$ & $0.05(0.02-0.11)(85)^{\mathrm{f}}$ & $0.10(0.09-0.12)(32)$ & $0.02(0.01-0.05)(85)^{f}$ & $0.06(0.04-0.10)(18)^{\mathrm{e}}$ \\
\hline Northern Ireland $^{a}$ & $0.06(0.05-0.08)(81)^{\mathrm{f}}$ & $0.17(0.15-0.19)(39)$ & $0.03(0.02-0.05)(81)^{\mathrm{f}}$ & $0.09(0.07-0.11)(29)$ \\
\hline Portugal $^{\mathrm{b}}$ & $0.15(0.09-0.26)(80)^{\mathrm{f}}$ & $0.25(0.17-0.36)(18)^{\mathrm{e}}$ & $0.07(0.05-0.10)(71)$ & $0.17(0.11-0.27)(18)^{\mathrm{e}}$ \\
\hline Romania $^{a}$ & $0.02(0.01-0.05)(85)^{\mathrm{f}}$ & $0.05(0.04-0.07)(39)$ & $0.01(0.002-0.02)(85)^{\mathrm{f}}$ & $0.02(0.01-0.04)(18)^{\mathrm{e}}$ \\
\hline Spain $^{\mathrm{a}}$ & $0.04(0.02-0.08)(89)^{\mathrm{f}}$ & $0.08(0.06-0.10)(18)^{\mathrm{e}}$ & $0.02(0.01-0.04)(89)^{f}$ & $0.05(0.03-0.07)(18)^{\mathrm{e}}$ \\
\hline
\end{tabular}

EU-WMH, European Union World Mental Health; CI, confidence interval.

${ }^{\text {a }}$ Part 1 weights.

${ }^{\mathrm{b}}$ Part 2 weights.

${ }^{\mathrm{c}}$ Model M9: adjusted for gender, marital status, urbanicity and employment status (i.e. married, employed, rural-dwelling males).

${ }^{\mathrm{d}}$ Model A9: adjusted for gender, marital status, urbanicity and employment status (i.e. married, employed, rural-dwelling males).

${ }^{\mathrm{e}}$ Lower age limit of participants diagnosed with disorder (country specific).

${ }^{\mathrm{f}}$ Upper age limit of participants diagnosed with disorder (country specific).

sometimes cited in support of this (Kuwert et al. 2008; Ardelt et al. 2010); other factors such as psychiatric morbidity or movement into residential care facilities may have removed these adults from the community. However, neither of the latter are likely to be deciding factors. Simulation studies have shown that death rates attributable to the reduced life-expectancy associated with mental disorders would have to be implausibly high among older adults to account for a decline in the prevalence of depression with age (Kruijshaar et al. 2005; Patten, 2007). Furthermore, the number of older adults in residential care facilities considered as a proportion of their peers is relatively small in most countries $(2.17 \%$ of adults in Northern Ireland over 65 years were in residential or nursing care in 2008; DHSSPSNI, 2008). 
Table 5. Estimated effects associated with determinants of mood and anxiety disorders: the EU-WMH project

\begin{tabular}{|c|c|c|c|c|}
\hline \multirow[b]{2}{*}{ Covariate } & \multicolumn{2}{|c|}{ Any mood disorder: Model M9 } & \multicolumn{2}{|c|}{ Any anxiety disorder: Model A9 } \\
\hline & OR (95\% CI) ( $p$ value) & $\begin{array}{l}\text { Change in OR per } \\
1 \text { year increase in age } \\
(95 \% \mathrm{CI})(p \text { value })\end{array}$ & OR (95\% CI) ( $p$ value) & $\begin{array}{l}\text { Change in OR per } \\
1 \text { year increase in age } \\
(95 \% \mathrm{CI})(p \text { value })\end{array}$ \\
\hline \multicolumn{5}{|l|}{ Gender } \\
\hline Male & 1 & - & 1 & - \\
\hline $\begin{array}{l}\text { Female (excluding } \\
\text { Belgium) }\end{array}$ & $2.10(1.84-2.39)(<0.001)$ & - & $2.60(2.33-2.89)(<0.001)$ & - \\
\hline $\begin{array}{l}\text { Female (Belgium } \\
\text { only) }\end{array}$ & $2.10(1.84-2.39)(<0.001)$ & - & $1.22(0.82-1.82)(0.317)$ & - \\
\hline \multicolumn{5}{|l|}{ Marital status } \\
\hline Married & 1 & - & 1 & - \\
\hline $\begin{array}{l}\text { Divorced (excluding } \\
\text { Portugal) }\end{array}$ & $2.28(1.93-2.69)(<0.001)^{\mathrm{a}}$ & $0.98(0.97-0.99)(0.001)$ & $1.23(1.07-1.41)(0.003)$ & - \\
\hline $\begin{array}{l}\text { Divorced (Portugal } \\
\text { only) }\end{array}$ & $2.28(1.93-2.69)(<0.001)^{\mathrm{a}}$ & $1.02(1.00-1.05)(0.07)$ & $1.23(1.07-1.41)(0.003)$ & - \\
\hline Never married & $1.29(1.07-1.56)(0.01)^{\mathrm{a}}$ & $0.99(0.98-1.00)(0.11)$ & $0.93(0.80-1.07)(0.31)$ & - \\
\hline \multicolumn{5}{|l|}{ Urbanicity } \\
\hline $\begin{array}{l}\text { Midsize (population } \\
\text { 10000-100000) } \\
\text { (excluding Belgium) }\end{array}$ & $1.09(0.93-1.27)(0.29)$ & - & $1.10(0.97-1.25)(0.12)^{\mathrm{a}}$ & $1.01(1.00-1.02)(0.24)$ \\
\hline $\begin{array}{l}\text { Midsize (population } \\
\text { 10000-100000) } \\
\text { (Belgium only) }\end{array}$ & $1.09(0.93-1.27) 0.29)$ & - & $0.54(0.36-0.80)(0.002)^{\mathrm{a}}$ & $1.01(1.00-1.02)(0.24)$ \\
\hline $\begin{array}{l}\text { Urban (population } \\
>100000) \text { (excluding } \\
\text { Romania) }\end{array}$ & $1.23(1.04-1.45)(0.02)$ & - & $1.10(0.96-1.25)(0.16)^{\mathrm{a}}$ & $1.01(1.00-1.02)(0.24)$ \\
\hline $\begin{array}{l}\text { Urban (population } \\
>100000) \text { (Romania } \\
\text { only) }\end{array}$ & $1.23(1.04-1.45)(0.02)$ & - & $1.10(0.96-1.25)(0.16)^{\mathrm{a}}$ & $1.04(1.02-1.07)(0.001)$ \\
\hline \multicolumn{5}{|l|}{ Employed } \\
\hline Working & 1 & - & 1 & - \\
\hline Student & $1.30(0.45-3.73)(0.63)^{\mathrm{a}}$ & $1.01(0.96-1.05)(0.80)$ & $2.15(0.98-4.72)\left(0.06^{\mathrm{a}}\right.$ & $1.03(0.99-1.06)(0.11)$ \\
\hline Home-maker & $1.16(0.94-1.43)(0.16)^{\mathrm{a}}$ & $1.00(0.98-1.01)(0.65)$ & $0.98(0.83-1.16)(0.81)^{\mathrm{a}}$ & $1.00(0.99-1.01)(0.95)$ \\
\hline Retired & $1.91(1.24-2.95)(0.004)^{\mathrm{a}}$ & $0.97(0.95-1.00)(0.02)$ & $1.68(1.22-2.32)(0.002)^{\mathrm{a}}$ & $0.98(0.96-0.99)(0.01)$ \\
\hline $\begin{array}{l}\text { Other (e.g. } \\
\text { unemployed) }\end{array}$ & $2.71(2.27-3.23)(<0.001)^{a}$ & $1.01(1.00-1.02)(0.08)$ & $1.92(1.64-2.25)(<0.001)^{a}$ & $1.01(1.00-1.02)(0.18)$ \\
\hline
\end{tabular}

EU-WMH, European Union World Mental Health; OR, odds ratio; CI, confidence interval.

${ }^{a}$ An individual of average age (46.9 years).

Overall, we remain unconvinced that estimates of the burden of mood and anxiety disorders according to standardized interviews across many countries are realistic and that older adults rarely, if ever, experience depression or anxiety. The Department of Health in England estimates that around $40 \%$ of older adults attending their doctor have a mental health difficulty (NIMHE, 2005). Figures from Northern Ireland show that, between 2007 and 2008, of the 13980 adults aged $\geqslant 25$ years who were designated mentally ill (excluding those with dementia) and in contact with their Health Care Trust, 10.2\% were aged $\geqslant 75$ years. Rates of death officially recorded as deaths by suicide per 100000 across Europe remain stubbornly high in older adults (EUROPA, 2008; Scowcroft, 2012).

There may be reasons for this discrepancy: older adults with prior or current mental illness may simply be opting out of the interview process. Research has shown that standardized diagnostic interviews may exceed the cognitive capacity of older adults (Knauper \& Wittchen, 1994), who are likely to give different answers to CIDI questions compared to similar questions posed using other instruments 
(O'Connor \& Parslow, 2009). Given the increasing number of countries participating in cross-national research and increases in life expectancy, it seems appropriate that the validity of the CIDI as an instrument for assessing mental disorders among older adults be addressed more fully.

\section{Differing relationships between prevalence and age across} countries

We noted wide differences in the prevalence levels of individual disorders across the EU-WMH. This may be due in part to the lack of established validity of the instrument in all these countries, particularly in Eastern Europe, and also to the fact that genuine cross-cultural differences exist. Northern Ireland and Portugal account for the highest prevalence of all Part $1 \mathrm{mood}$ and anxiety disorders in the EU-WMH. There may be several possible reasons for this: these surveys, the last EU-WMH studies to be completed, were undertaken at a time of increasing economic uncertainty. The high levels of mood and anxiety disorders in these countries may reflect an association between deprivation and mental illness (Kuruvilla \& Jacob, 2007); in 2009 both Portugal and Northern Ireland reported the lowest GDP per capita of all Western European countries participating in the EU-WMH (EUROPA, 2012). The particularly high levels of mood disorders in Northern Ireland are likely to be associated with the civil conflict of the second half of the twentieth century known as 'the troubles' (Davidson \& Leavey, 2010).

No simple geographical pattern exists that summarizes the relationship between prevalence and age for all disorders. The lowest levels of mental disorders are reported in Italy, Romania and Bulgaria, with the prevalence of both mood and anxiety disorders increasing with age in Bulgaria. It has been suggested that the increasing prevalence of mood disorders with age in some Eastern European countries is associated with the breakdown of communist governments in the 1990s and the declining economic circumstances, which have affected the oldest adults most severely (Tomov et al. 2004). Lack of research prior to the EU-WMH means that it is not possible to determine whether this is true or not. In Romania there is a lack of active ageing strategies and older adults retire early, face feelings of futility and have low levels of social engagement. Mental illness in Bulgaria has been described as 'an irreversible condition, which strips the sufferer of all their mental faculties' (Coleman et al. 2011). The relatively low levels of mental disorders among the youngest adults here may be genuine or a reflection of stigma or low mental health literacy.
We have also noted the very high levels of anxiety disorders in adults in Portugal and Belgium among younger adults. Portugal has experienced economic difficulties consistently throughout the first decade of the twenty-first century, with increasing levels of youth unemployment, and this may be reflected in our results. Alternatively, younger adults may have a more keenly developed sense of mental health literacy.

Effects associated with gender, marital status, urbanicity and employment status across the lifespan

As noted previously, similarities in individual mental health determinants across countries have been observed. We have now tested this observation formally and noted that effects associated with variables such as gender, marital status, employment and urbanicity on the odds of mood or anxiety disorders are generally homogeneous across the EU-WMH. Not only are these effects similar but also the ways in which they vary with age are similar. This may be in part a result of the multigroup strategy; in a multilevel analysis of data gathered from 23 countries participating in the European Social Survey (ESS-3), random slopes models reported significant variation across countries in the effects of gender, education and employment after adjusting for age in depression as measured by the Centre for Epidemiologic Studies Depression Scale (CES-D; Van de Velde et al. 2010). To explore this matter further, the analyses could be repeated across a wider selection of countries and a greater variety of control variables incorporated.

There were some exceptions to the above result. There was no significant gender effect on the odds of any anxiety disorder in Belgium (OR 1.2, 95\% CI $0.8-1.8, p=0.4)$. This contrasts with another Belgian study (LaPierre, 2009) that reported a strong statistical association of female gender with pure depression, pure anxiety disorder and co-morbid depression/ generalized anxiety in the adult population $(p<0.0001$ in all cases). The effect associated with divorce on mood disorders decreased with age in all countries $(p<0.001)$ apart from Portugal. It may be that younger adults experience more undesirable life events than older adults and have fewer coping resources (Jang et al. 2009). The Portuguese observation tallies with longitudinal studies that suggest that the association of divorce with mental illness increases rather than decreases with age (Breslau et al. 2011).

The odds of any anxiety disorder in Belgium for adults of average age was significantly lower in mid-sized regions (10000-100000 inhabitants) regions compared to rural regions $(<10000$ inhabitants). Although noted elsewhere in the EU-WMH literature (Kovess-Masfety et al. 2005), this result sits outside 
the general body of literature, which suggests that as population density increases so does the odds of mental illness (Dekker et al. 2008), or that urbanicity effects disappear once other variables such as age and socio-economic status are taken into account (Kovess-Masfety et al. 2005). It is possible that this result is an artefact of constraining the urbanicity categories to be the same across countries and this may change when a more country-sensitive measure of urbanicity is used.

\section{Conclusions}

In this study we have used multigroup methods to explore the distribution of several determinants of mental disorders across the adult lifespan within selected EU countries. Effects associated with common determinants such as gender and marital status are relatively homogeneous across countries. Mental disorders are relatively uncommon among the oldest adults surveyed, at least in Western Europe. We contend that this result is unlikely to be realistic and warrants formal validity studies of the CIDI among this age group. The lack of validation in older adults is a concern that does not always seem to be fully appreciated; furthermore, it is a concern that is not limited to one country but may apply to many. We believe it would be erroneous for policy makers, at times of economic restraint, to conclude on the basis of our results that there was little need to invest in the mental well-being of older adults in Western Europe or in younger adults in the East and to concentrate resources elsewhere. This would make it even more difficult for adults who required such help to seek and receive it. Conversely, in countries where prevalence is genuinely low at certain stages in the lifespan, such information could aid the development of positive mental health strategies seeking to reduce the burden associated with these illnesses in other countries.

\section{Supplementary material}

For supplementary material accompanying this paper visit http://dx.doi.org/10.1017/S0033291713001116.

\section{Acknowledgements}

This work was supported by the EU Contribution to the World Mental Health (WMH) Surveys Initiative (EU-WMH) project (EAHC 20081308) and by the European Study of the Epidemiology of Mental Disorders (ESEMeD) project (QLG5-1999-01042; SANCO 2004123); the Piedmont Region (Italy), Fondo de Investigación Sanitaria, Instituto de Salud
Carlos III, Spain (FIS 00/ 0028), Ministerio de Ciencia y Tecnología, Spain (SAF 2000-158-CE), Departament de Salut, Generalitat de Catalunya, Spain, Instituto de Salud Carlos III (CIBER CB06/02/0046, RETICS RD06/0011 REM-TAP), and other local agencies and by an unrestricted educational grant from GlaxoSmithKline. The primary author was funded by the Department of Education and Learning for Northern Ireland (DELNI). This project is carried out in conjunction with the World Health Organization World Mental Health (WMH) Survey initiative. We thank the WMH staff for assistance with instrumentation fieldwork, and data analysis. A complete list of WMH publications can be found at http://www.hcp. med.harvard.edu/wmh/.

\section{Declaration of Interest}

None.

\section{References}

Aiken LS, West SG (1991). Multiple Regression: Testing and Interpreting Interactions. SAGE: London.

Alonso J, Angermeyer MC, Bernert S, Bruffaerts R, Brugha TS, Bryson H, de Girolamo G, Graaf R, Demyttenaere K, Gasquet I, Haro JM, Katz SJ, Kessler RC, Kovess V, Lépine JP, Ormel J, Polidori G, Russo LJ, Vilagut G, Almansa J, Arbabzadeh-Bouchez S, Autonell J, Bernal M, Buist-Bouwman MA, Codony M, Domingo-Salvany A, Ferrer M, Joo SS, Martínez-Alonso M, Matschinger $\mathrm{H}$, Mazzi F, Morgan $\mathrm{Z}$, Morosini P, Palacín C, Romera B, Taub N, Vollebergh WA; ESEMeD/MHEDEA 2000 Investigators (2004a). Sampling and methods of the European Study of the Epidemiology of Mental Disorders (ESEMeD) project. Acta Psychiatrica Scandinavica 109 (Suppl. 420), 8-20.

Alonso J, Angermeyer MC, Bernert S, Bruffaerts R, Brugha TS, Bryson H, de Girolamo G, Graaf R, Demyttenaere K, Gasquet I, Haro JM, Katz SJ, Kessler RC, Kovess V, Lépine JP, Ormel J, Polidori G, Russo LJ, Vilagut G, Almansa J, Arbabzadeh-Bouchez S, Autonell J, Bernal M, Buist-Bouwman MA, Codony M, Domingo-Salvany A, Ferrer M, Joo SS, Martínez-Alonso M, Matschinger H, Mazzi F, Morgan Z, Morosini P, Palacín C, Romera B, Taub N, Vollebergh WA; ESEMeD/MHEDEA 2000 Investigators (2004b). Prevalence of mental disorders in Europe: results from the European Study of the Epidemiology of Mental Disorders (ESEMeD) project. Acta Psychiatrica Scandinavica 109 (Suppl. 420), 21-27.

Andrews G, Henderson S, Hall W (2001). Prevalence, comorbidity, disability and service utilisation: overview of the Australian National Mental Health Survey. British Journal of Psychiatry 178, 145-153.

APA (1994). Diagnostic and Statistical Manual of Mental Disorders, 4th edn. American Psychiatric Publishing: Arlington, VA. 
Ardelt M, Landes SD, Vaillant GE (2010). The long-term effects of World War II combat exposure on later life well-being moderated by generativity. Research in Human Development 7, 202-220.

Aromaa E, Tolvanen A, Tuulari J, Wahlbeck K (2011). Predictors of stigmatizing attitudes towards people with mental disorders in a general population in Finland. Nordic Journal of Psychiatry 65, 125-132.

Bou J, Satorra A (2010). A multigroup structural equation approach: a demonstration by testing variation of firm profitability across EU samples. Organizational Research Methods 13, 738-766.

Breslau J, Miller E, Jin R, Sampson NA, Alonso J, Andrade LH, Bromet EJ, de Girolamo G, Demyttenaere K, Fayyad J, Fukao A, Galaon M, Gureje O, He Y, Hinkov HR, Hu C, Kovess-Masfety V, Matschinger H, Medina-Mora ME, Ormel J, Posada-Villa J, Sagar R, Scott KM, Kessler RC (2011). A multinational study of mental disorders, marriage, and divorce. Acta Psychiatrica Scandinavica 124, 474-486.

Bromet E, Andrade LH, Hwang I, Sampson NA, Alonso J, de Girolamo G, de Graaf R, Demyttenaere K, Hu C, Iwata N, Karam AN, Kaur J, Kostyuchenko S, Lepine JP, Levinson D, Matschinger $\mathrm{H}$, Mora ME, Browne MO, Posada-Villa J, Viana MC, Williams DR, Kessler RC (2011). Cross-national epidemiology of DSM-IV major depressive episode. BMC Medicine 9, 90.

Bromet EJ, Gluzman SF, Paniotto VI, Webb CPM, Tintle N, Zakhozha V, Havenaar JM, Gutkovich Z,

Kostyuchenko S, Schwartz JE (2005). Epidemiology of psychiatric and alcohol disorders in Ukraine: findings from the Ukraine World Mental Health Survey. Social Psychiatry and Psychiatric Epidemiology 40, 681-690.

Byrne BM (2011). Structural Equation Modelling with Mplus. Routledge: New York.

Coleman PG, Carare RO, Petrov I, Forbes E, Saigal A, Spreadbury JH, Yap A, Kendrick T (2011). Spiritual belief, social support, physical functioning and depression among older people in Bulgaria and Romania. Aging and Mental Health 15, 327-333.

Cook RD, Weisberg S (1982). Residuals and Influence in Regression. Chapman and Hall: New York.

Copeland JR, Dewey ME, Griffiths-Jones HM (1986). A computerized psychiatric diagnostic system and case nomenclature for elderly subjects: GMS and AGECAT. Psychological Medicine 16, 89-99.

Davidson G, Leavey G (2010). Promoting mental health in Northern Ireland: addressing division, inequality and stigma. Journal of Public Mental Health 9, 6-15.

Dekker J, Peen J, Koelen J, Smit F, Schoevers R (2008). Psychiatric disorders and urbanization in Germany. BMC Public Health 8, 17.

DHSSPSNI (2008). Adult Community Statistics: 1st April 2007-31st March 2008. Department of Health, Social Services and Public Safety: Northern Ireland (www. dhsspsni.gov.uk/adult-community-statistics07-08.pdf). Accessed 17 December 2012.

Ernst C, Angst J (1995). Depression in old age: is there a real decrease in prevalence? A review.
European Archives of Psychiatry and Clinical Neuroscience 245, 272-287.

EUROPA (2008). Suicide-Related Deaths in an Enlarged European Union (http://ec.europa.eu/health/mental_health/ eu_compass/reports_studies/anamort.pdf). Accessed 17 December 2012.

EUROPA (2012). Regional GDP per Capita in 2009: Seven Capital Regions in the Ten First Places (http://europa.eu/rapid/ pressReleasesAction.do?reference=STAT/12/38\&format= HTML\&aged=0\&language=EN\&guiLanguage=en). Accessed 1 April 2012.

Ferry F, Bolton D, Bunting B, Devine B, McCann B, Murphy S (2008). Trauma, Health and Conflict in Northern Ireland. A study of the epidemiology of trauma related disorders and qualitative investigation of the impact of trauma on the individual. Northern Ireland Centre for Trauma and Transformation and University of Psychology Research Institute, Londonderry (www.nictt.org/attachments/article/ 22/NICTT\%20THC\%20in\%20NI.pdf). Accessed 17 December 2012.

First MB, Spitzer RL, Gibbon M, Williams JBW (1995). User's Guide for the Structured Clinical Interview for DSM-IV Axis I Disorders (SCID-I/P) (Version 2.0). Biometrics Research Department, New York State Psychiatric Institute: New York.

Florescu S, Ciutan M, Popovici G, Galaon M, Ladea M, Pethukova M, Hoffnagle A (2009). The Romanian Mental Health Study: main aspects of lifetime prevalence and service use of DSM-IV disorders. Management in Health 13, 22-29.

Fuentes K, Cox BJ (1997). Prevalence of anxiety disorders in elderly adults: a critical analysis. Journal of Behavior Therapy and Experimental Psychiatry 28, 269-279.

Giannakouris K (2008). Ageing Characterises the Demographic Perspectives of the European Societies (http://epp.eurostat.ec. europa.eu/cache/ITY_OFFPUB/KS-SF-08-072/EN/ KS-SF-08-072-EN.PDF). Accessed 30 May 2012.

Gibb SJ, Fergusson DM, Horwood LJ (2011). Relationship separation and mental health problems: findings from a 30-year longitudinal study. Australian and New Zealand Journal of Psychiatry 45, 163-169.

Green SB, Babyak MA (1997). Control of Type I errors with multiple tests of constraints in structural equation modeling. Multivariate Behavioral Research 32, 39-51.

Greenland S, Maclure M, Schlesselman JJ, Poole C, Morgenstern H (1991). Standardized regression coefficients: a further critique and review of some alternatives. Epidemiology 2, 387-392.

Guerra M, Ferri CP, Sosa AL, Salas A, Gaona C, Gonzales V, de la Torre GR, Prince M (2009). Late-life depression in Peru, Mexico and Venezuela: the 10/66 population-based study. British Journal of Psychiatry 195, 510-515.

Haro JM, Arbabzadeh-Bouchez S, Brugha TS, Girolamo G, Guyer ME, Jin R, Lepine JP, Mazzi F, Reneses B, Vilagut G, Sampson NA, Kessler RC (2006). Concordance of the Composite International Diagnostic Interview Version 3.0 (CIDI 3.0) with standardized clinical assessments in the WHO World Mental Health Surveys. 
International Journal of Methods in Psychiatric Research 15, 167-180.

Honkonen T, Virtanen M, Ahola K, Kivimaki M, Pirkola S, Isometsa E, Aromaa A, Lonnqvist J (2007). Employment status, mental disorders and service use in the working age population. Scandinavian Journal of Work, Environment and Health 33, 29-36.

Jang S, Kawachi I, Chang J, Boo K, Shin H, Lee H, Cho S (2009). Marital status, gender, and depression: analysis of the baseline survey of the Korean Longitudinal Study of Ageing (KLoSA). Social Science and Medicine 69, 1608-1615.

Jeste DV, Blazer DG, First MB (2007). Aging-related diagnostic variations: need for diagnostic criteria appropriate for elderly psychiatric patients. In Age and Gender Considerations in Psychiatric Diagnosis: A Research Agenda for DSM-V (ed. E. William, M. B. First, P. J. Sirovatka and D. A. Regier), pp. 273-288. American Psychiatric Publishing: Arlington, VA.

Kaplan D, Wenger RN (1993). Asymptotic independence and separability in covariance structure models: implications for specification error, power, and model modification. Multivariate Behavioral Research $\mathbf{2 8}$ 467-482.

Kessler RC (2006). The epidemiology of depression among women. In Women and Depression: A Handbook for the Social, Behavioral, and Biomedical Sciences (ed. C. L. M. Keyes and S. H. Goodman), pp. 22-37. Cambridge University Press: New York.

Kessler RC, Abelson J, Demler O, Escobar JI, Gibbon M, Guyer ME, Howes MJ, Jin R, Vega WA, Walters EE, Wang P, Zaslavsky A, Zheng H (2004). Clinical calibration of DSM-IV diagnoses in the World Mental Health (WMH) version of the World Health Organization (WHO)

Composite International Diagnostic Interview (WMH-CIDI). International Journal of Methods in Psychiatric Research 13, 122-139.

Kessler RC, Birnbaum H, Bromet E, Hwang I, Sampson N, Shahly V (2010). Age differences in major depression: results from the National Comorbidity Survey Replication (NCS-R). Psychological Medicine 40, 225-237.

Kessler RC, Üstün TB (2004). The World Mental Health (WMH) Survey Initiative Version of the World Health Organization (WHO) Composite International Diagnostic Interview (CIDI). International Journal of Methods in Psychiatric Research 13, 93-121.

Knauper B, Wittchen HU (1994). Diagnosing major depression in the elderly: evidence for response bias in standardized diagnostic interviews? Journal of Psychiatric Research 28, 147-164.

Kovess-Masfety V, Lecoutour X, Delavelle S (2005). Mood disorders and urban/rural settings: comparisons between two French regions. Social Psychiatry and Psychiatric Epidemiology 40, 613-618.

Kruijshaar ME, Barendregt J, Vos T, de Graaf R, Spijker J, Andrews G (2005). Lifetime prevalence estimates of major depression: an indirect estimation method and a quantification of recall bias. European Journal of Epidemiology 20, 103-111.
Kuruvilla A, Jacob KS (2007). Poverty, social stress and mental health. Indian Journal of Medical Research 126, 273-278.

Kuwert P, Knaevelsrud C, Rosenthal J, Dudeck M, Freyberger HJ, Spitzer C (2008). Quality of life and sense of coherence in former German child soldiers of World War II. Psychiatrische Praxis 35, 399-403.

LaPierre TA (2009). Marital status and depressive symptoms over time: age and gender variations. Family Relations 58, 404-416.

MacCallum RC, Zhang S, Preacher KJ, Rucker DD (2002). On the practice of dichotomization of quantitative variables. Psychological Methods 7, 19-40.

McDougall FA, Kvaal K, Matthews FE, Paykel E, Jones PB, Dewey M, Brayne C (2007). Prevalence of depression in older people in England and Wales: the MRC CFA study. Psychological Medicine 37, 1787-1795.

Muthén LK, Muthén BO (1998-2013). Mplus User's Guide, 6th edn. Muthén \& Muthén: Los Angeles, CA.

Newman SC, Sheldon CT, Bland RC (1998). Prevalence of depression in an elderly community sample: a comparison of GMS-AGECAT and DSM-IV diagnostic criteria. Psychological Medicine 28, 1339-1345.

NIMHE (2005). Facts for Champions. National Institute for Mental Health in England, Department of Health: London.

Oberski D (2009). J-Rule for Mplus (https://github.com/daob/ JruleMplus/wiki). Accessed 1 July 2011.

O'Connor DW (2006). Do older Australians truly have low rates of anxiety and depression? A critique of the 1997 National Survey of Mental Health and Wellbeing. Australian and New Zealand Journal of Psychiatry 40, 623-631.

O'Connor DW, Parslow RA (2009). Different responses to K-10 and CIDI suggest that complex structured psychiatric interviews underestimate rates of mental disorder in old people. Psychological Medicine 39, 1527-1531.

Patten SB (2007). An animated depiction of major depression epidemiology. BMC Psychiatry 7, 23.

Prina AM, Ferri CP, Guerra M, Brayne C, Prince M (2011). Co-occurrence of anxiety and depression amongst older adults in low- and middle-income countries: findings from the 10/66 study. Psychological Medicine 41, 2047-2056.

Riedel-Heller SG, Busse A, Angermeyer MC (2006). The state of mental health in old-age across the 'old' European Union - a systematic review. Acta Psychiatrica Scandinavica 113, 388-401.

Rogler LH, Malgady RG, Tryon WW (1992). Evaluation of mental health: Issues of memory in the Diagnostic Interview Schedule. Journal of Nervous and Mental Disease 180, 215-222.

Rotermann M (2007). Marital breakdown and subsequent depression. Health Reports 18, 33-44.

Saris WE, Satorra A, van der Veld WM (2009). Testing structural equation models or detection of misspecifications? Structural Equation Modeling 16, 561-582.

Schaub RT, Linden M, Copeland JR (2003). A comparison of GMS-A/AGECAT, DSM-III-R for dementia and depression, including subthreshold depression (SD) - results from the 
Berlin Aging Study (BASE). International Journal of Geriatric Psychiatry 18, 109-117.

Scott KM, Von Korff M, Alonso J, Angermeyer M, Bromet EJ, Bruffaert R, de Girolamo G, de Graaf R, Fernandez A, Gureje O, He Y, Kessler RC, Kovess V, Levinson D, Medina-Mora ME, Mneimneh Z, Browne MAO, Posada-Villa J, Tachimori H, Williams D (2008). Age patterns in the prevalence of DSM-IV depressive/anxiety disorders with and without physical co-morbidity. Psychological Medicine 38, 1659-1669.

Scowcroft E (2012). Suicide Statistics Report 2012: Data for 2008-2010. Samaritans: London.

Selig JP, Card NA, Little TD (2008). Latent variable structural equation modeling in cross cultural research: multigroup and multilevel approaches. In Multilevel Analysis of Individuals and Cultures (ed. F. J. R. van de Vijver, D. A. van Hemert and Y. H. Poortinga), pp. 93-119. Taylor \& Francis Group/Lawrence Erlbaum Associates: New York.

Snowdon J (2001). Prevalence of depression in old age. British Journal of Psychiatry 178, 476-477.

StataCorp (2009). Stata Statistical Software, Release 11. StataCorp LP: College Station, TX.

Tomov T, Hinkov H, Zarkov Z, Mladenova M, Vasilev S, Okolyiski M (2008). National Representative Epidemiological Survey of Common Mental Illness in Bulgaria. Social Medicine 4, 16-21.

Tomov T, Mladenova M, Lazarova I, Sotirov V, Okoliyski M (2004). Bulgaria mental health country profile. International Review of Psychiatry 16, 93-106.
Van de Velde S, Bracke P, Levecque K (2010). Gender differences in depression in 23 European countries. Cross-national variation in the gender gap in depression. Social Science and Medicine 71, 305-313.

van der Veld WM, Saris WE, Satorra A (2008). JRule 3.0: User's Guide (www.vanderveld.nl). Accessed 17 December 2012.

Weinberg CR (1995). How bad is categorization? Epidemiology 6, 345-347.

Weng G (2010). Statistical Analysis of Pearson Residuals in Survey Logistic Regression Diagnosis (www.amstat.org/ sections/srms/proceedings/y2010/Files/308783_61605.pdf). Accessed 30 May 2012.

Wetherell JL, Petkus AJ, McChesney K, Stein MB, Judd PH, Rockwell E, Sewell DD, Patterson TL (2009). Older adults are less accurate than younger adults at identifying symptoms of anxiety and depression. Journal of Nervous and Mental Disease 197, 623-626.

Wittchen HU, Jacobi F, Rehm J, Gustavsson A, Svensson M, Jonsson B, Olesen J, Allgulander C, Alonso J, Faravelli C, Fratiglioni L, Jennum P, Lieb R, Maercker A, van Os J, Preisig M, Salvador-Carulla L, Simon R, Steinhausen HC (2011). The size and burden of mental disorders and other disorders of the brain in Europe 2010. European Neuropsychopharmacology 21, 655-679.

Wolter KM (2007). Introduction to Variance Estimation, 2nd edn. Springer Science+Business Media: New York.

Woodal A, Morgan C, Sloan C, Howard L (2010). Barriers to participation in mental health research: are there specific gender, ethnicity and age related barriers? BMC Psychiatry 10, 103. 